\title{
The Between Story: Physical and Psychic Trauma in the Poetry of Sonia Sanchez and Lucille Clifton
}

\author{
Chanae D. Bazemore \\ Hunter College, Master of Arts Degree, New York, USA \\ e-mail: chanae.bazemore@gmail.com
}

Received: 8 November 2012; Accepted: 14 May 2013

\begin{abstract}
Rhetorical choices used by Black women poets makes their work a militant force in the theoretical war against racist and sexist oppression. Research on trauma and testimony supports a breakdown of the person's or character's sudden brush with death -a moment that will never be fully realized, however it is at the center of explicating the rhetorical signs of trauma. Through a reading of Sonia Sanchez's poems "Wounded in the House of a Friend" (Sanchez, 1995: 5), "Poem for Some Women" (Sanchez, 1995: 72), "Eyewitness: Case No. 3456" (Sanchez, 1995: 70), and "Poem at Thirty" (Sanchez, 1985: 4), with Lucille Clifton's "My Friends" (Clifton, 1987: 147), "Shapeshifter Poems" (Clifton, 2000: 52), and "Song at Midnight" (Clifton, 1993: 24), my analysis will trace how traumatic wounding constitutes a psychic wound. It then applies the racialized and gendered reading of the subjects in the poem (insidious trauma), and how time and space relates to the subjects, space, and silences (traumatic realism). With the use trauma theory, I will illustrate how Sanchez and Clifton's aesthetic forms adapted the militancy of the Black Arts Movement to address the silenced voices. In particular, the silenced voices of subjects continually subsumed beneath the phallocentric undertones challenged by Black feminist discourse, art, and poetry will be addressed.
\end{abstract}

KEYWORDS: Trauma theory; Insidious trauma; Traumatic realism; Feminist poetry; Racism; Sexism.

Citation I Cómo citar este artículo: Bazemore, C.D. (2013) "The Between Story: Physical and Psychic Trauma in the Poetry of Sonia Sanchez and Lucille Clifton". Culture \& History Digital Journal 2(2): e030. doi: http://dx.doi. org/10.3989/chdj.2013.030

RESUMEN: 'The Between Story': trauma físico y psíquico en la poesía de Sonia Sánchez y Lucille Clifton.- Las opciones retóricas utilizadas por las poetas negras hacen de su trabajo una herramienta militante en la batalla teórica contra la opresión racista y sexista. Investigar sobre el trauma y el testimonio conlleva una crisis de la persona o el carácter, repentinamente teñidos con la muerte - un momento nunca por entero realizado-, que sin embargo está en el centro de la explicación de los signos retóricos del trauma. Mediante la lectura de los poemas de Sonia Sánchez "Wounded in the House of a Friend" (Sanchez, 1995: 5), "Poem for Some Women" (Sanchez, 1995: 72), "Eyewitness: Case No. 3456" (Sanchez, 1995: 70) y "Poem at Thirty" (Sanchez, 1985: 4), así como "My Friends" (Clifton, 1987: 147), "Shapeshifter Poems" (Clifton, 2000: 52) y "Song at Midnight" (Clifton, 1993: 24) de Lucille Clifton, muestra mi análisis cómo la herida traumática conforma una herida psíquica. Además aplica enfoques de raza y de género a la lectura de los sujetos del poema (el trauma insidioso), y a cómo el tiempo y el espacio se relacionan con individuos, lugar y silencios (realismo traumático). Utilizando la teoría del trauma, quiero así ilustrar cómo las formas estéticas de S. Sánchez y L. Clifton adaptaron la militancia del Black Arts Movement al tratamiento de voces silenciadas. Abordaré en particular las voces silenciadas de sujetos permanentemente sometidos a connotaciones falocéntricas, esas que son desafiadas por el discurso, el arte y la poesía del feminismo negro.

PALABRAS CLAVE: Teoría del trauma; Trauma insidioso; Realismo traumático; Poesía feminista; Racismo; Sexismo

Copyright: (C) 2013 CSIC. This is an open-access article distributed under the terms of the Creative Commons Attribution-Non Commercial (by-nc) Spain 3.0 License. 
"At the core of these stories, I would suggest, is thus a kind of double telling, the oscillation between a crisis of death and the correlative crisis of life: the between story of the unbearable nature of an event and the story of the unbearable nature of its survival. These two stories, both incompatible and absolutely inextricable."

(Caruth, 1996: 3) Cathy Caruth

Unclaimed Experience

"Progressive Black women artists have shown ongoing concern about healing our wounds. Much of the celebrated fiction by black women writers are concerned with identifying our pain.” (Hooks, 1993: 15) bell hooks

Sisters of the Yam

In various media amongst the arts, literature, and cinema, trauma narratives and testimonies are used to comment on past and present political and historical events. Through the male-dominated public discourse surrounding the Black Arts Movement, Black women writers sought to find their voice. Many of the images created in their writings mirror larger feminist dialogues surrounding the Black female body. Contemporary artist Kara Walker's work, for instance, explicitly addresses sex, gender, race and sexuality. The image of the negress is often seen in her silhouette cuts as a martyr for social injustices. In Burn, created in 1998, the negress lights herself on fire, defiantly taking control of her life, ironically through death (Walker, 1998). As Yasmil Raymond suggests in "Maladies of Power: A Kara Walker Lexicon", the definitive message in this type of suicide is both an "act of transgression and empowerment" (Raymond, 2007: 354). Raymond highlights the destructive capabilities of silenced voices. From an earlier generation and using a different art form, poets Sonia Sanchez and Lucille Clifton share with Walker the ease with which they convey "calculated acts of rebellion", and the ways in which they (re)define how trauma is authentically addressed in their work (Raymond, 2007: 344).

Sanchez and Clifton use poetry to challenge the silences that affect African American life, particularly the lives of African American women, and subsequently the literature. Born in 1934, activist, poet, and playwright Sonia Sanchez was raised in Alabama. After moving to Harlem and attending school in New York, her writing and presence in black culture evolved as she became involved in the Black Arts Movement. Also associated with BAM, actress, writer, and advocate Lucille Clifton was born in New York in 1934. After her death from uterine cancer in 2010, Clifton's work continues to be a staple in collections of poetry especially those geared towards the female body. Their candid interpretations of race, class, and gender, particularly sexual and psychosocial traumas on the Black oppose the repeated silencing of that body's truths. Using the critical discourse of trauma to analyze Clifton and Sanchez's poetry, in this thesis I will justify reading their work as a traumatic restatement. Essentially, their poetry on rape, incest, violence, and sexuality give voice to these often silenced subjects. These issues have remained a vital part of their aesthetic even after the Black Arts Movement -where silence persistently used as a social weapon.

Sanchez and Clifton's use of "[t]raumatic figurative language is the means with which many poets are able to articulate that which is by normal means unrepresentable" (Baker, 2012: 87). Embedded in these traumatic restatements are the threat of death and the prospects of survival. A theoretical analysis of trauma and testimony reveals a breakdown of the person's or character's sudden brush with death -a moment that will never be fully realized, but that is at the center of explicating the rhetorical signs of trauma. Via a reading of Sanchez's poems "Wounded in the House of a Friend" (Sanchez, 1995: 5), "Poem for Some Women" (Sanchez, 1995: 72), "Eyewitness: Case No. 3456" (Sanchez, 1995: 70), from her eponymous work Wounded In The House of a Friend and "Poem at Thirty" (Sanchez, 1985: 4) published in I've Been A Woman, with Lucille Clifton's "My Friends" republished in the memoir Good Woman (Clifton, 1987: 147), "Shapeshifter Poems" from her Blessing the Boats collection (Clifton, 2000: 52), and "Song at Midnight" (Clifton, 1993: 24) from The Book of Light, my analysis will trace how traumatic wounding constitutes a psychic wound. It then applies the racialized and gendered reading of the subjects in the poem (insidious trauma), and how time and space relates to the subjects the space and the silences (traumatic realism); subsequently addressing this unveils how their aesthetic forms were adapted from Black Arts aesthetics. Through trauma theory, we see how this poetry continued the militancy of the Black Arts Movement to address the silenced voices of those subjects continually subsumed beneath the phallocentric undertones challenged by Black feminist discourse, art, and poetry.

A facet of psychoanalytic theory, trauma theory is derived from the works of Sigmund Freud and Jacques Lacan. From their analyses, Cathy Caruth gauged the traumatic wound as a signifier of trauma theory. Conclusions drawn from his patient observations in his 1895 work "Studies in Hysteria", Freud framed his perception of "psychical trauma" (Caruth, 1996: 12) which later added to the completion of "The Origin and Development of Psychoanalysis" in 1910. In other words, the assertion that trauma forces out memories that cannot be articulated or expressed by the subject was developed from Freud's theories on psychoanalysis. Lacan takes this idea a step further. Instead of solely exhibiting an inability to be vocalized, the traumatic event is literally expressionless. Not only is the subject not 
able to access the traumatic event, there are no words to formulate the occurrence. As Freud, Lacan, and subsequently Caruth makes clear, the constant repetition of what cannot be put into words becomes the "real" trauma -in and of itself (Lacan, 1988: 164).

Considering trauma theory through a Black feminist perspective supports the theories of "insidious trauma" on marginal subjects (Grogan, 2011: 1-2; Root, 1992: 242). My work draws upon the psychoanalytic research of Cathy Caruth and Maria Root. Aligning with the critical conversations of trauma theory, the poetry I am considering here reflects the human condition as it relates to white privilege and the patterns of trauma in Black literature. These connections appear repeatedly in the poetry of the late 20th century. Unlike poetry of their contemporaries that focused on the nationalist and revolutionary Black men who dealt with freedom rights and liberation, the Sanchez and Clifton poems I examine in this thesis comment on everyday Black men, the fathers, brothers, and friends who participate in the cyclical traumatic experiences of Black women. Some attention to earlier work by poets like Jayne Cortez and June Jordan can help clarify this distinction.

Changes in music and poetry framed Black voice, identity, and consciousness during the Black Arts Movement. Poetry associated with the Black Arts Movement consistently comments on the physical and mental traumas on the Black female body as a political statement on race. Jayne Cortez's 1984 poem on the misogyny in "If the Drum Is a Woman", and her 1982 poem "Rape", enables the victims to remove the violence done to their bodies by killing their rapists. In her poem "If the Drum is A Woman", Cortez constructs a discourse on race and gender within a paradigm of white supremacist social and economic hierarchies, which were incessantly challenged by Black men. As an effect, Cortez uses sounds and silences to illuminate instances of misogyny and violence in a heteronormative space of Black men and women. Cortez responds to the sexist undertones of Duke Ellington's "What Else Can You Do with a Drum", which situates Black women as object in their own cultural realm. Using the drum as a metaphor, Cortez retraces the Black woman as subject rather than object. She also critiques Black men's participation in continuing to silence Black women. Without removing Black women from the focus of the poem, Cortez also addresses the Black man's dilemma: "striped with flames" from whippings, and "underpaid" (Frost and Hogue, 2006: 82). However, she does not allow herself or the reader to express pity for Black man's struggle with being economically and socially antagonized by whites. His depravity is not an excuse to dominate Black women. Cortez implores Black men not to "be forced into the position / as an oppressor of drums" (Frost and Hogue, 2006: 83). Also of the Black Arts generation, June Jordan's militant poems
"The Rationale", "She Drove Me Crazy", and "Poem about My Rights" express radical politics. Seen explicitly in the latter, Jordan uses the female body as a point of reference for international political injustices and their rape as a metaphor (Jordan, 2005: 167, 208). Her poem "draws some striking parallels between sexual violence against individual women and neo-colonial violence against people and nations" (Davis, 1985: 2). Certainly there are numerous Black women writers who have impacted the Black Arts Movement, as well as subsequent feminist and Black liberation movements.

The relationships between Black women writers during the various liberation movements were just as important as the militant works they produced. Clifton affirms: "Sonia and I are such good friends because we don't write alike. Particularly when I was first writing, African American writers didn't particularly ... validate what I did because it did not seem to be political, forgetting what Gwendolyn Brooks said -that when she walked out of her door, it was a political decision" (Davis, 2002: 1066). Because of this misconception about Clifton's work there is a lack of scholarship that "addresses [Clifton's] treatment of gender, race, and ethnicity within social and cultural frameworks" (Cucinella, 2002: 78). In the psychoanalytic works of trauma theorists Judith Herman, Cathy Caruth, and Dori Laub there is an innate obligation by the victim to become involved in the trauma narrative, testimony, and witnessing (Herman, 1992: 10-20). This thesis will support the ability of poetry to act as an art of trauma. Sanchez and Clifton tackle rape, child sexual abuse, and domestic battery, as well as sexism within the Black community. These traumas are several amongst a list of concerns tackled by Sanchez and Clifton, and are interpreted through a distinctly Black female voice.

\section{TRAUMA AND THE PSYCHIC WOUND}

Most often associated with the Black Arts Movement, Sanchez and Clifton thoughtfully challenged both racism and phallocentric spaces enforced by Black male writers -who expected Black women to support the Movement's agenda. More importantly when the "ideologies of the 1960s said black, they meant black male", addressing these issues have continued to impact the writing of Black women poets (Christian et al., 2007: 60). Sanchez addresses the need for human connection over Movement radicalism in her prose poem "Just Don't Never Give Up on Love", from her collection of poetry Homegirls and Handgranades (Sanchez, 1984: 29), in which she shared the experiences of past loves and loss. Sanchez juxtaposes the speaker's voice with that of an older woman. Searching for sublime inspiration in an insipid world, the speaker initially sees in the 84-year-old woman a "bamboo-creased body" while the old woman sees in the speaker "the 
pulse of the winds", and "the noise of dragonflies" (Sanchez, 1984: 30, 31). The images of nature in this poem are metaphors for the life untouched by the speaker and the rebirth the older woman suggests she find by not giving up on love. The speaker doesn't want "rap from the roots today. [She] needs the present" (Sanchez, 1984: 30). From their talk, she finds out that Mrs. Johnson has "lived life instead of writing about it" (Sanchez, 1984: 32). By the end the speaker is thankful for the lesson she's learned from the woman, and the roots (growth) she experienced from the talk: "I cried. For myself. For this woman talking about love. For all the women who have ever stretched their bodies out anticipating civilization and finding ruins" (Sanchez, 1984: 32). Searching for humanity in spite of the traumatic experiences that have plagued her life, she compares the story of two generations and traces to a collective experience of Black women. An experience framed by wounds that are passed down, relived, and exacerbated through stories and narratives of the wounded.

Explicitly seen in Sanchez's "Eyewitness: Case No. 3456" (1995), rape was often written about as an unpunished crime when Black women were the victim. Sanchez's prose can be read as a narrative interpretation of trauma. She creates a voice for both victim and rapist. Trauma theory suggests trauma narratives are a means to testify to the psychosexual and physical unhealable wound created when sexual abuse is committed on a body that is not considered defensible (Caruth, 1996: 4). She opens the poem, "i was raped at 3 o'clock one morning. I was sleeping in my bedroom in the back part of my house" (Sanchez, 1995: 69). By avoiding giving a face to the rapist in the text, and an identity to the victim, Sanchez situates "Eyewitness" as a testimony for the collective trauma of women whose victimizers were rarely brought to justice for rape. Although published in 1995, Sanchez's analysis of rape was still a vital part of the fight for women's rights.

Caruth asserts in Unclaimed Experience that trauma narratives consist of "the oscillation between a crisis of death and the correlative crisis of life: the between story of the unbearable nature of an event and the story of the unbearable nature of its survival. These two stories, both incompatible and absolutely inextricable" (Caruth, 1996: 3). This "between story" is what makes Sanchez's poetry a restatement of the collective trauma affecting Black women. The following moment in "Eyewitness" is a paradigmatic example: "[he] began to move the knife across my body, making little nicks. Said he could make me less a woman if he cut off my breasts ... he hit me in the head and pushed my mouth flat down on the bed. I cdn't breathe. i thought i would suffocate then and there" (Sanchez, 1995: 69-70). The crude details included in the poem intensify this traumatic retelling of rape. The crisis of death is experienced as she loses breath while her face is fixed to the bed, however, the crisis of life comes with the threat of her rapist removing her "womanhood". The rape signifies the wound that is unhealable, while the little nicks heal into scars but become a constant reminder of the traumatic event (Caruth, 1996: 4). These moments are separate, yet, related because they speak to the rhetorical framework of interpreting trauma.

Adhering to Shoshana Felman's theory of trauma that "[b]y extension, the listener to trauma comes to be a participant and a co-owner of the traumatic event: through his very listening, he comes to partially experience trauma in himself" (Felman and Laub, 1991: 57), the story of a traumatic event is embedded in the psyche of both reader and writer of the event. Sanchez calls herself (assumed as the speaker) an eyewitness to the events of the poem. The possibility of death and the story of survival illuminate bell hooks' assertion in Sisters of the Yam that identifying pain and healing wounds is a vital experience of Black writers (Hooks, 1993: 15). However, the application of trauma theory to Black literature reveals a second, psychic wound that, as this reading of poetry shows, is impossible to heal.

In Sharon Marcus' essay, 'Fighting Bodies, Fighting Words: A Theory and Politics of Rape Prevention" (2002), Marcus describes the "rapescript" in which she analyzes "the rapist's feelings of powerfulness" in concert with "female bodies as vulnerable, violable, penetrable, and wounded ... conceived as a delicate, perhaps inevitably damaged and pained inner space" (Marcus, 2002: 171, 180). Reading this dialogue puts the reader in a position to witness both sides of the rape. The wound is reflected in both the mind and the body by way of Marcus' assertion that the female organ is already a wound, and Laub's claim that through listening the trauma becomes partially the reader's as well. Experiencing both forces the witness of this trauma to be psychically wounded by re-witnessing the traumatic event. Referencing Marcus and Carine Mardorossian's feminist theories on rape, (Mardorossian, 2002: 743) Janice Haaken's review of the rape script is invaluable here. She asserts, "[w]hile cultural feminists would not deny the reality of sexual violence nor its traumatic impact on victims, they are more theoretically engaged in the scripting and discursive elaboration of female sexual victimization than they are in the direct effects of bodily assaults" (Haaken, 2002: 782). We see this in Sanchez's poetry:

\footnotetext{
When i awoke in the morning he was gone. i dragged myself out of the bed ... ran out of the house, to the porch, and felt the blood on my legs held the blood in my hand saw that the morning had returned and put on my face (Sanchez, 1995: 70).
}

In these closing lines of the poem, Sanchez does not suggest that the victim sought any type of justice. 
Instead she ends the scene saying she "put on [her] face". This suggests that she went on with life, not accepting what has happened, but rather internalizing her wound.

Through the earlier analysis of the rapist and the rape victim's voice, the use of "i" in the poem, along with the lurid description of her touching the blood on her legs, creates images of the traumatic event taking place in that moment further illuminating the omnipresent narrative voice. This also speaks to the impossibility of linear temporality in traumatic retelling. Waking up the next morning and reliving the traumatic events as she touches the blood, she has to go on without consequence a constant, but fragmented, reminder of what has happened in the memories of the event.

Sanchez's colloquial prose in the following lines of "Eyewitness" acknowledges the colloquial and figurative language extended from the Black Arts Movement, an aesthetic used by her contemporaries Ntozake Shange and Nikki Giovanni. Sanchez uses an excess of Black vernacular to accentuate the voice of the male speaker, shocking the reader into the traumatic experience and differentiating the act and the voice from that of the victim.

move yo ass bitch cmon move yo ass i'm gon give you a fuck like you aint never had and as he talked he got harder and harder ... bitch say it's good it feels good tell me how juicy it is tell me how you love the pain go on talk to me about big Black dicks and suckin big black dicks yeh here i come with mine (Sanchez, 1995: 69-70).

In her poetry Sanchez is not only commenting on the psychosexual abuse of Black women, she is also illuminating the naturalized images of “"oversexed' Black men" (Haaken, 2002: 784). Sanchez's representation of both the rapist and rape victim from the first-person omniscient point of view -where both use "ip" - puts the reader of the traumatic event in the position to interpret the inextricable voices as a necessity for rebuilding the conflicting relationships between Black men and women. By exploring the voices of both victim and rapist, Sanchez is fusing these voices. This action points to a larger framework. The legacy of violence inflicted on African Americans, a legacy that includes destruction of the community from within, emphasizes the inability to read these voices as distinctly separate (Spillers, 1987: 75). The inimical image of the Black male rapist works in Sanchez's poem to accentuate our understanding that both Black men and women are in some way wounded. She does not look to excuse the behavior, yet emphasizes the reality that it does exist. Like the importance she places on her students' realization that mental captivity still plagues the Black community, in her poetry she affirms that without freedom from oppression there can be no escape from the violence breeding within the Black community. This comes through most clearly in the closing lines of the poem, which lack any hope for justice, because raping Black women was continually and systematically neglected.

Sanchez's authorial voice is authenticated through the willingness to take a humanistic stance in relation to the African American experience. Her ability to access this voice comes from her cognizance of the history, progress, and struggle within and outside of the Black community. In Wendy Hesford's analysis of rhetorical matters within witness testimony she contests: "survivor narratives so expose oppressive material conditions, violence, and trauma; give voice heretofore silent histories; help shape public consciousness about violence against women; and thus alter history's narrative" (Hesford, 2004: 195). In "Eyewitness", Sanchez's use of repetition gives the reader the ability to read her poetry as a survivor's narrative. This use of repetition is illustrated in the following lines of the poem "Eyewitness" where the rapist speaks grimly to the victim: "don't you look at me he screamed as he moved the knife toward my vagina. Don't you open yo mouth or yo eyes or you dead. Bitch. Bitch. Yeh. Bitch. Bitch (Sanchez, 1995: 69). Sanchez complies with Audre Lorde's rejection of silences that would suggest a glorification of nothingness in Black women's psyches and in turn in their literature. Without diluting her examination of abused women or the complex roles of Black men, Sanchez addresses a guiltless voice of both victim and perpetrator. As Lorde asserts in "Age, Race, Class and Sex", voice and truth are important factors in addressing the violence within African American communities. Lorde notes that "hostility against Black women is practiced not only by the white racist society, but implemented within our Black communities as well. It is a disease sticking the heart of Black nationhood, and silence will not make it disappear" (Lorde, 1984: 4).

This analysis speaks to events in Sanchez's poem, such as the rapist's silencing of the victim as he tells her not to speak or look at him -in other words, not to witness what is happening to her (until he initiates the aforementioned "rape-script" to situate his domain over her). The repetition of "Black bitch" also initiates the psychic inscriptions of trauma onto the Black woman's body. As he rapes her, calling her a Black bitch demoralizes her through her race and her psyche. Again, this deconstructs the Black woman's dilemma with suffering a double wound. As a racialized subject she historically has signified as object. Her "womanhood" is considered a separate entity from her body. Rendered voiceless in this moment, by the end the woman is seen "put[ting] back on [her] face" (Sanchez, 1995: 70). Her traumatic figurative language suggests that 
there was nothing left but to restore the life back to her self and continue on. Inaccessible at the time of the traumatic event, the poem acts as a testimony for the silenced.

Shifting from the wound that is born out of the Black man through the image of perpetrator in the previous poems, Clifton's "Song At Midnight" and Sanchez's "Poem At Thirty" address the Black male subject as a stranger/enemy. Both speakers attempt to counsel the men in these poems. While "Poem At Thirty" is one of Sanchez's earlier poems, I use it here in comparison to "Song At Midnight" since Clifton uses a part of Sanchez's poem as her epigraph. Although written years later, Clifton's usage of Sanchez's poem sets the tone for her admonitions. In "Poem At Thirty", a dusky, ethereal description of a woman's recollection of a life less emboldened by passion, Sanchez explains:

\author{
no one touches \\ me anymore. \\ father do not \\ send me out \\ among strangers. \\ you you Black man \\ stretching scraping \\ the mold from your body. \\ here is my hand. \\ i'am not afraid \\ of the night. (Sanchez, 1995: 23-33)
}

In both poems Sanchez and Clifton speak directly to and of Black men. Clifton asks, "brothers, / who will hold her, / who will find her beautiful / if you do not?" (Clifton, 1987: 24). These poems represent the pleading to fathers for protection, and to friends for endearment, and to both to create healthy relationships in the Black community. Focusing on the Black man's role and removing the female body and physical descriptions from these poems, results in the creation of a dialogue about the damaged psyches and traumatic effects of stereotypes about the Black female subject. This rhetorical choice temporarily removes the importance of the physical wound from the reader, in order to speak to and about social, political, and intimate aspects of Black women's lives. Erin Wunker's analysis of the "autofictional 'I" speaks to the fearless assertions Clifton and Sanchez make -and the lack of descriptions of the body in these particular poems.

\footnotetext{
The Freudian female subject is estranged from her own body. This bodily estrangement demands that the subject adapt her conception of her self, both physical and psychical ... this adaptation severs the (female) subject's inherent connection with her body: This psychic adaptation -there is nothing endemic to time itself that makes it impossible for the body to relive it (Wunker, 2007: 156).
}

Confronted by racist and sexist provincialisms that marginalize Black women's bodies in literature, Sanchez and Clifton abstract the female subject's body in order to address the psychic wound. This distinct distance from the body gives the writer a chance to remove the audience from the harsh realities of the trauma, and tie in the wound of the self/ mind. In doing so, the psychic wound is read in the poetry as timeless. The wound repeats itself in Sanchez and Clifton's poetry because these traumas continued to be active in the sociopolitical climate of the late 20th century.

In her article "Trauma Theory; Contexts, Politics, Ethics", Susannah Radstone (2007) addresses the relationship between witnessing and testimony in her analysis of Caruth and Laub: "[testimony] demands a witness and it is only within the context of witnessing that testimony to trauma is possible ... grounded in the space between witness and testifier within which that which cannot be known can begin to be witnessed" (Radstone, 2007: 20). In differentiating the perspectives of Black men and Black women in the poems, with their interrelated experiences with violence and racism, the following analyses are vital to my research. In The Trouble Between Us: An Uneasy History of White and Black Women in the Feminist Movement, Winifred Breines (2006) deconstructs the problematic relationship between men and women in the African American community:

[B]lack women were and wanted to be loyal to black men, and they longed for black men to be loyal to them. But many men were not, and the women were hurt ... Adding insult to injury, some male writers used the supposedly overbearing characteristics of the black woman to defend the black man's 'escape' to the white woman. Black women's hurt, anger, confusion and resentment crystallized around interracial liaisons between black men and white women ... What does it mean when a black man spurns his own women for outsiders? (Breines, 2006: 62-63).

I would consider Clifton's "Song At Midnight" here, which relates to "Poem At Thirty" and according to my analysis of Sanchez, reflects a similar double bind. The Black male subject's presence as perpetrator and victim is an issue for both authors. Black men are positioned as a witness to, and source of, the recurring racial and gendered oppression through rape, incest, and other forms of traumatic psychical and psychic wounding in the Black women's poetry associated with the Black Arts Movement. This wounding remains a theme in the poetry created after the BAM without diluting the critique of abused women or the complex roles of Black men woven into the fabric of their poetry.

In "Song at Midnight" Clifton uses lines from Sanchez's "Poem at Thirty" as her epigraph: "do 
not send me out among strangers". Both poems end with a declaration of endurance. Sanchez proclaims her voice as a tool for change when she asserts " $\mathrm{i}$ ' am not afraid / of the night" and Clifton's insistence that "everyday / something has tried to kill me/ and has failed" (Sanchez, 1995: 31-32; Clifton, 2000: 25). The speakers of these poems recognize that Black men, although affected by white supremacy, are still the dominant force in the male/female binary, subsequently reinforcing the need for Black women's resistance in the social and domestic spheres. Each speaker mourns the lack of a figure to look up to in her attempt to find a voice: "won't you celebrate with me / what i have shaped into / a kind of life? / i had no model / (...) both nonwhite and woman / (...) i made it up" (Clifton, 2000: 25). Clifton materializes a woman, comfortably gendered, racialized, and unapologetic for her creation from nothing. She challenges Pamela Barnett's assertion that a Black woman's body is "caught between conflicting narratives - the vulnerable female body, the sexual and the contagious black body - none of which account for the specificity of her coding" (Barnett, 1997: 19). From this analysis comes a fortitude in the face of trauma and pain that shifts the psychic pain into a reflection of an enduring Black female subject. In this poetry, the listener plays a specific role in the experience. The poetry demands a familiarity with Black experience, which includes cognizance of sexism and racism as interlocking oppressions.

\section{INSIDIOUS TRAUMA}

Sanchez and Clifton analysis of gender and race, created a dialogue about the domestic as a significant part of the political framework of Black liberation theories. According to Michele Wallace's interpretation of the intricacies surrounding Black domestic life in Black Macho and the Myth of the Superwoman, the rationalization of the Black "strong" woman as the enemy has been repeatedly made in literature and society equally (Wallace, 1979: 31). Addressed in Sanchez and Clifton's poetry is the analysis of social traumas affecting Black men and women, which are at times ignored by Black men who lack "awareness of the oppression of Black women" (Wallace, 1979: 120). Coined by Maria Root, the term "insidious trauma" suggests the aspects of trauma that are attached to and repeated through cultural, queer, racial, gendered, class, and socio-economic structures.

In Sanchez and Clifton's poetry, "insidious trauma" is used to unveil the wounds expressed in "Wounded in the House of a Friend" (1995) and "My Friends" (1987) in their depiction of Black domestic life. By making the private and domestic space a political space in "Wounded in the House of a Friend" and "My Friends", respectively, Sanchez and Clifton address issues in the poems that counter the existing phallocentric mindset and address sexuality the way it has historically been deemed "taboo" (West, 1993: 88). They assert a Black male voice with as much vigor as that of the African American woman. These poets are illustrating the positive and the negative aspects of the Black struggle for humanity. The references to the body, specifically Sanchez's "I will become a collector of me ... and put meat on my bones" (Sanchez, 1995: 7), and Clifton's expression of being, in spirit "limbless / but whole" in the poetry is "the human cost of remaining silent" (Clifton, 1987: 147). The counter the effects of silence, through comparisons to the body as a wound, are made to be a metaphor for a lack of humanity in the domestic spaces they create in these poems. They address the discrepancies in Black domestic spaces that were rarely addressed because they were either seen as taboo, according to West, or historically seen as irrelevant (in the Black Arts Movement).

Sanchez and Clifton's poetry are exemplifies the ways poetic language can be used as a traumatic restatement of the collective trauma of Black women. This is explicitly captured in Sanchez's "Wounded in the House of a Friend" and Clifton's "My Friends". In her work on trauma theory, "Bearing Witness, or the Vistitudes of Listening," Dori Laub asks a vital question in the overall act of witnessing and testimony: "What can we learn from the trauma, from the testimony and from the very process of our listening?" (Laub, 1992: 74). It is not just the colloquial language adapted by Black female poets to situate their identity and spaces in the literary canon. It is also seen in these particular poems that use the linguistic and thematic effects associated with the BAM. Yet Sanchez and Clifton's poetry went above the misogynist undertones of the era. They created a distinctly feminist space and often addressed sexual abuse, battery, gender and racism in the same manner their male cohorts, like LeRoi Jones (Amiri Baraka) and Larry Neal, addressed Black manhood, the nationalist and political agenda rejecting homosexuality and attention to "white-controlled institutions ... male poets in the BAM defined and reified revolutionary Black male identity" (Pollard, 1994: 173, 266). When their poems are analyzed through trauma theory, they illustrate an undertone of the source of Black pain and cyclical themes of injustice. Sanchez and Clifton's poems formulate a space for African Americans to locate the source of their pain through the journey rather than dwelling in the static existence of being psychically and psychically wounded.

Sanchez's 1995 collection Wounded in the House of a Friend unapologetically bespeaks the cyclical nature of socioeconomic turmoil, drug, child, and sexual abuse within the Black community. She painstakingly addresses not only the connections slavery still has in the disenfranchisement 
of Black people, but also the Black man's role in creating a psychic wound in the collective consciousness of African American women. Wounded in the House of a Friend is a commentary on the constant psychosexual abuse of Black women. In trauma theory, to be "wounded" brings along connotations not only connected to the corporeal, but also imbedded in the repetitive resurfacing of the traumatic event in the psyches of the victim. These poems engage in a voice for both the male and female victims. In Sanchez and Clifton's work the issue is not whether their experiences parallel the testimony of the poetry; rather, their aesthetic is formed to capture a story that conveys the "insidious trauma".

An eponym of the book's title, the opening poem "Wounded in the House of a Friend" stages a dialogue between victim and oppressor, in a domestic space. Sanchez's use of friend factors into her analysis of Black sexuality. The juxtaposition of the poem's title and its form matches the tumultuous space of the man and wife in the poem. "House" and "friend", words that usually take on positive connotations in texts, are used here to underline and juxtapose the wound present in the domestic space between Black men and women in the poem. The form of the prose poem constructs a voice that is true to both sides of a story told less often of the domestic struggles of violence, abuse, and silencing in the Black community -rather than those more visible in the political spheres.

The use of eyes and indocility in the relationship of the man and wife in "Wounded" function as a narrative of the ongoing acquiescence of the woman: "the unspoken word is born, $i$ see it in our eyes dancing", "[i]t had been on her face in her eyes", "always looking for trouble", "[i]t is pretty like this nite. Like his eyes", "[a]nd she'd climb on him. Close her eyes" (Sanchez, 1995: 3-4, 6-7). The shift in voices, italics to signify the woman's voice, normal text to signify the husband's, also counters Sanchez's authorial voice as it deconstructs public and private spaces. This rhetorical and structural choice unmasks the militancy imbedded in the more than often silenced domestic spaces of African American relationships. More importantly, this dialogue about Black men and women is affected by the stereotypes embedded in Black life throughout history. Sanchez depicts the Black man's voice in the text as sexually promiscuous. The speaker admits, "[t]here was another woman. In fact there were three women ... No sex for months. Always tired or sick or off to some conference designed to save the world from racism or extinction" (Sanchez, 1995: 3). The wife is encumbered and deceived for being dedicated to a cause outside of her husband.

The male and female identities are performed, deconstructed, and reconstructed into a caricature of what men expect from their wives. Sanchez's speaker asks the following questions of her husband's mistresses:

$$
\begin{aligned}
& \text { "Are they married?" } \\
& \text { one is } \\
& \text { They're like you then. } \\
& \text { yes. } \\
& \text { (...) } \\
& \text { What do they do }
\end{aligned}
$$

An accountant and two lawyers

They're like you then.

yes. (Sanchez, 1995: 4-5)

Shifting into what she expects her husband to want, the omniscient voice Sanchez takes on in the poem highlights the results of a woman who acquiesces. He says, "[i]t ain't normal is it for a wife to fuck like she does ... it aint normal. Like it aint normal for a woman you've lived with for twenty years to act like this" ... "you're my wife. it's not normal to fuck as much as you do. No?" ... "if $i$ become thel other woman will i be / loved like you loved her?" (Sanchez, 1995: 7-8, 10). There is recurrence of expectations without support, and demand without reciprocation. In the poem the wife begins to feel worthless: " $i$ know what to do now. i'll go outside and give it away. Since he doesn't really want me. My love. My body ... What to do now. Go outside and give it away. Pussy. Sweet. Black pussy. For Sale" (Sanchez, 1995: 8-9). Her body is exploited. By rejecting that script of submission, Sanchez has created an aesthetic that addresses the essentialist male and female binary constructed through cultural trauma.

As "Wounded" continues, there are fragments and abstracted storylines that are consistent with a traumatic restatement. Towards the end the husband and wife's dialogue is paralleled. Fast paced fragmented prose, places gone and "(Luggage received damaged. torn. broken. Scratched. Dented. Lost) ... (A lot of questions no answers. Long lunches. Laughter. Penises. Flirting. Touches. Drinks. Cunts and Coke. Jazz and Jacuzzis.) (Morning. Evening. Received. Damaged. Torn. Broken. Dented. Scratched. Lost.)" (Sanchez, 1995: 9-10). This shift in rhetorical technique manifests as a reaction to trauma and addresses the wound directly. The husband reacts poorly to the wife's attempt to turn the tables and strategically repair the "torn. [and] broken" parts of their relationship, by metaphorically changing herself into what a wife is not supposed to be -sexual. The juxtaposition of their alliterations and fragments illuminates the presence of trauma in both voices. In other words, these literary devices are "pointing to what is 'between the lines' and beneath the many surfaces of the event" (Laub and Podell, 1995: 1000). At the end of "Set No. 1" there is a repetition of: " $i$ shall become a collector of me ... AND PUT MEAT ON MY SOUL" (Sanchez, 1995: 10). The repetition of the phrase, sometimes 
in caps, at times being all one word, is a rhetorical sign of trauma. The first line in italics relates to the woman's dialogue but the mixture of fonts signifies a (re)telling or (re)creation of a story. It is a rejection of the acquiescence showed to please -a rejection of a coded narrative between man and woman. Published close to a decade apart, "Wounded In the House of a Friend"(1995) and Lucille Clifton's "My Friends"(1987) closely parallel one another in their representations of trauma in regards to social, cultural, gendered, and racial divides in Black domestic spaces that abstract the presence of trauma in both male and female perspectives.

In Clifton's poem "My Friends" there are various phallocentric images to counter the sexuality and feminist voice of the speaker:

when i throw them off and slide

like a marvelous snake toward your bed

your box whatever you will keep me in

no they will not understand what can be

... what is to me worth all appendages.

they will never understand never approve

of me loving at last where i would

throw it all off to be,

with you in your small room limbless

but whole. (Clifton, 1987: 18)

Slaves were usually whipped for disobeying their masters, in particular for their very human reactions to inhumane treatment. For example, slave women were beaten for refusing to sleep with their masters and for expressing emotions when their children were taken away and sold. Black men were whipped for attempting to defend their families, looking their masters in the eyes, or trying to run away.

Slavery, and specifically the "domestic spaces" created for slaves, are interpreted through the slave narrative because of its relationship to a historical trauma represented in the Black "home." Such implications of trauma are apparent in Harriet Jacobs' slave narrative, Incidents in the Life of a Slave Girl. Her narrative did not follow the conventional focus on literacy, extreme scenes of physical violence, or the spectacle of mutilated Black bodies -the tropes Henry Louis Gates highlights as a part of the slave narrative form. Instead, Jacobs' work highlights the pain enforced on her mentally, the psychological wounds she suffered in order to protect her "innocence", and the pain inflicted on other women who were still enslaved at the time Incidents was published (Jacobs, 1987: 530). My analysis of Jacobs' slave narrative here is not to trace historical trauma of rape from those that took place during slavery to the rape poetry of Sanchez and Clifton. Rather, this analysis is constructed in order to show how the silences and wounds created through the text in Black women's writing are readable, through trauma theory, in both genres. These rhetorical choices can be defined in the poetry, art, and slave narrative forms as a continuous dialogue created by social oppressions and approached in the literature.

Jacobs' scrutiny of sexual abuse in slavery, of the reactions of white women, and of the relationship of psychic pain to sexual abuse are seen here as vital ways Black women writers found to write about their injustices. In these characters/voices in "Wounded" and "My Friends", Sanchez and Clifton relate experiences in the text that mirror the sociopolitical atmosphere during the mid-late twentieth century. Tracing these social conditions to the themes in the poetry affirms that social oppressions are accounted as a traumatic wound read and countered in Sanchez and Clifton's poetry. For the female subject, not only is her body subject to pain; her mind serves as its conduit. Along the same lines, Clifton situates the spectacle of mutilated Black bodies; a trope Henry Louis Gates posits as apart of the slave narrative form. Both texts "mak[e] an important distinction between the impact of trauma on ongoing memory formations, crucial to ... the focus on the memory of trauma" (Brown, 2004: 787). Clifton and Sanchez confront the ontological issues that define them as poets in a phallocentric space. These poets are challenging their compartmentalization as artists, while connecting their fight, as women, to those an equally important political agenda.

\section{TRAUMATIC REALISM}

The fragments, inconsistencies, and silences read in trauma narratives are read in the poetry as an inability of the speaker to capture the totality of the traumatic event. In his book Traumatic Realism, Michael Rothberg (2000) defines the theory as:

Marked by the survival of extremity into the every-
day world and is dedicated to mapping the complex
temporal and spatial patterns by which the absence of
the real, a real absence, makes itself felt in the familiar
plentitude of reality ... [in trauma there is] a demand
for documentation, a demand for reflection of the for-
mal limits of representation (Rothberg, 2000: 7).

The following analysis shows how the voice of a drug addicted mother in Sanchez's "Poem for Some Women" (1995), repeats the vicarious experience of trauma in mother-daughter relationships. Read in relation to "Poem for Some Women", Clifton's "Shapeshifter Poems" (2000) will show the trauma passed down through an incestuous father-daughter relationship. This section shows where parental relationships lie on the spectrum of traumatic realism and wound repetition.

Time and place play an important role in the construction of "Poem for Some Women" as a traumatic testimony. With the same blatant fervor as in her other poem, Sanchez sets the scene with the 
harsh realities of child sexual abuse and drug abuse. At the beginning of the poem Sanchez not only accounts for the particular space she is analyzing, she also points out in the title that it is for "some women" (Sanchez, 1995: 71). This situates these troubled women in a particular population of Black women whose testimony presents another variation in the collective experiences of trauma in the lives of Black women. In this poem time is not only an important factor for the temporal disorientation later in the poem, it also sets up a critical scene in the enigmatic testimony: "took my 7 yr old to / the crack house with me / on Thursday / Wanted her to know how / hard it is for me you / know a single woman / out here on her own you know" (Sanchez, 1995: 71-72). Both poems speak to the inequity Black women experience in social spheres because of their sex. However, "Poem for Some Women" goes further into the specific space of a single drug-addicted mother. The material and abstract features of this poem offer a discourse on the traumatic narrative that Dori Laub says "cannot be heard and of a story that cannot be witnessed" (Laub, 1992: 68). The unnamed child, however gendered and racialized, is also shaped by her socioeconomic status. Sanchez's "Poem for Some Women" foregrounds the transgenerational traumatic experience of Black women, by highlighting the wound-transference from parent to child. By bringing her daughter into the space that has stripped her of her ability to nurture she has inflicted that experience on her child, making her body and psyche susceptible to the wounds her race and gender have already exposed her to.

Although the woman in the poem is a drug addict and the trauma is mostly based on the sexual abuse she allows to happen to her daughter, as witness, she is internalizing her own traumatic experiences, as an exploited subject, and bearing witness to her daughter's trauma. The effects are conscious and subconscious. In "Poem for Some Women" the mother explains the following dream about her daughter: "i dreamed she was dead / I dreamed she was / surrounded by panthers who tossed her back and forth nibbling / and biting and tearing her up" (Sanchez, 1995: 74). In his 2008 article "Trauma and traumatic neurosis: Freud's concepts revisited", Siegfried Zepf deconstructs how dreams act under the influence of traumatic events. He claims "it is more likely that, in their dreams, the victims attempt to assure themselves of the fitness of their ego-functions that had failed in the traumatic situation" (Zepf and Zepf, 2008: 332). Bearing in mind that the mother Sanchez writes about in "Poem for Some Women" is subsumed by both her own and her child's traumatic experiences, we see how this explication of dreams applies. Her dream of panthers tearing her daughter apart is a defense mechanism for the harsh realities of her addiction and the Black men who are exploiting her. In other words, the man who molests her daughter in exchange for the drugs she requests mirrors the panthers -metaphors for the Black Panthers - and the death before they tear her apart mirrors her silenced voice as she allows her daughter to be molested. The traumatic event has no "beginning, no ending, no before, no during, and no after", as every situation is now seen in relation to and to come out of the traumatic event (Laub, 1992: 69). Furthermore, Sanchez's use of death and dreams can also be read as a metaphor for the historical and current degradation of Black women within their own cultural realms. Subsequently, the Black woman becomes an object whose thoughts and actions within the Black activists' struggle resulted in "tearing [her] up"; the male Black activists both reject her and use her as tool in their own search for power (Sanchez, 1995: 74)

As Kara Walker's art reminds us, sexual abuse and the innocence of children were witnessed in the antebellum South, and have evolved into the collective wounding of Black women and their female children in literature and media. Sanchez strategically homogenized these subjects. In "Poem for Some Women", she eerily comments on child and sexual abuse. While offering herself to another man for drugs, he tells her "i want her. i need / a virgin. Your pussy's / too loose" (Sanchez, 1995: 72). Sanchez's blatant talk of sex and mixture of iconic childhood nursery rhymes exemplifies the rhetorical signs of trauma throughout the text. In an italicized section of the poem, and when performed she sings: "Momma's little baby / loves shortening shortening / Momma's little baby / loves shortening bread" (Sanchez, 1995: 73). Adapted from the African folk song, "Shortn'in Bread" (Johnson, 1990: 259) was usually improvised while all renditions kept with the some form of the chorus, just as Sanchez situates it in "Poem for Some Women". In his analysis of "race blues", Guy R. Johnson critiques the sexual undertones in the original version of the song in the article "Double Meaning in the Popular Negro Blues". The exploitation of "race blues" artists, and the willingness for whites to change this song into marketable versions, is reflected in Sanchez's use of the "cleaner" version. However, the adaptation in "Poem for Some Women" reflects the sexual undertones in the original, when read through the lens of trauma theory. The original version of the song reads:

Two little niggers layin' in bed,

One turned over to the other an' said,

My baby loves short'nin', short'nin' bread,

My baby loves short'nin bread. (Johnson, 1990: 261)

In what Johnson refers to as "Negro slang" he situates the use of "bread", "cookie", and "cake", as a bawdy term for the female genitalia. He also asserts that "Short'nin' Bread", "had a vulgar meaning, and even when recorded in its supposedly innocent versions retains an undercurrent of sexual 
meaning" (Johnson, 1990: 261). The shift from "My baby" to "Momma's baby" does not strip the song of its sexual overtones; rather, this shift in wording keeps it in line with the psychosexual visual connections Walters makes to the traumatic historical debasement, and their relation to the present day constructs of Black women and men as marginalized and exploitable subjects. The children in each song are in some way shaped by the lasciviousness intrinsic to the lyrics. Correlating this song and Johnson's analysis to this traumatic reading further makes Sanchez's poem a critique of the perverse elements inflicted on the child in the poem. The ironic insertion of a song, which in modern times is used as a lullaby, in the midst of the traumatic narrative of a mother and daughter recalls the fragmented images of the mother as nurturer and lost innocence of her daughter. The sexual nature of the song also attaches to the analysis of the female body, specifically her genitalia, as a wound. Now that he daughter's "wound" has been opened in exchange for drugs, her traumatic experience resurfaces in everything -even the lullaby.

Christine Courtois' analysis of "counter transference" and "vicarious traumatization" can also be applied to a maternal psychic wounding through the mother's attempt to erase the abuse from the physical space and traumatic memories (Courtois, 1997: 466). It also has a clear connection to Clifton's "Shapeshifter Poems". Her poem is a trauma narrative/testimony about father-daughter incest. The fathers' inability to protect and nurture their daughters is an issue that comes up often in Clifton's poetry. he asks, "who / will protect her this prettylittlegirl" (Clifton, 2000: 78). The spaces, hyphenated lines, all a prevalent sign in trauma narratives. Trauma is realized in the written form through these rhetorical choices. Through her analysis of incest and the traumatic wound it creates in the child, Clifton also creates a dialogue on the overall effect reflected on the men participating, and their internalized trauma: "[t]he original trauma is located in the system of slavery that robbed African Americans of their bloodlines and condoned incest between white masters and their Black daughters in order to increase the stock of slaves" (Roberts, 2005: 1071). By the end of the poem, Clifton factors in reactions to a world and a people that are flawed.

\author{
the poem at the end of the world \\ is the poem the little girl breathes \\ into her pillow the one \\ she cannot tell the one \\ there is no one to hear this poem \\ is a political poem is a war poem is a \\ universal poem but is not about \\ these things this poem \\ is about one human heart this poem \\ is the poem at the end of the world (Clifton, 2000: 80)
}

The fourth section of "Shapeshifters" attempts to erase the violent silencing brought about by trauma, and to offer a humane critique of life after the wounding from a woman revisiting a girl from the past. She is rejecting and conceptualizing the pain into the traumatic narrative. Regarding the dominating and often violent presence of Black men in Sanchez's and Clifton's poetry, bell hooks makes a vital point which supports the oppressive tone the men are often made to exemplify in the poems. Considering bell hooks' analysis of Black male masculinity Grogan asserts: "we should not dismiss the scarring effects patriarchy has on men in teaching them to be emotionally unavailable and that patriarchy is particularly dehumanizing for men without class and race privilege" (Grogan, 2011: 21). To answer why, is not to express empathy nor is it to validate violence. However, these poets were commenting on the significance of writing about how racial oppression effects gender, particularly from Black women's perspective.

Ntozake Shange's choreopoem "For Colored Girls Who have Considered Suicide / When the Rainbow is Enuf" (1977) touches on many issues addressed in Sanchez's Wounded in the House of a Friend. Traumatic psychic wounds affect Black women in both texts. Both writers interpret the wounds inflicted on African American females without the threat of consequences by sexist men. Shange writes: "women relinquish all personal rights / in the presence of a man / who apparently cd be considered a rapist / especially if he has been considered a friend" (Shange, 1977: 34). Trauma is situated in the silences and rhetorical choice of the author in each poem. Sanchez's tone in "Poem for Some Women" does not imply judgment of the drug addict mother she speaks of, but her silences illuminate the traumatic images in her mind as the addict witnesses the trauma unraveling on her daughter's body. She bears witness in the following lines as she is rendered voiceless by her participation in the opening of her daughter's wound:

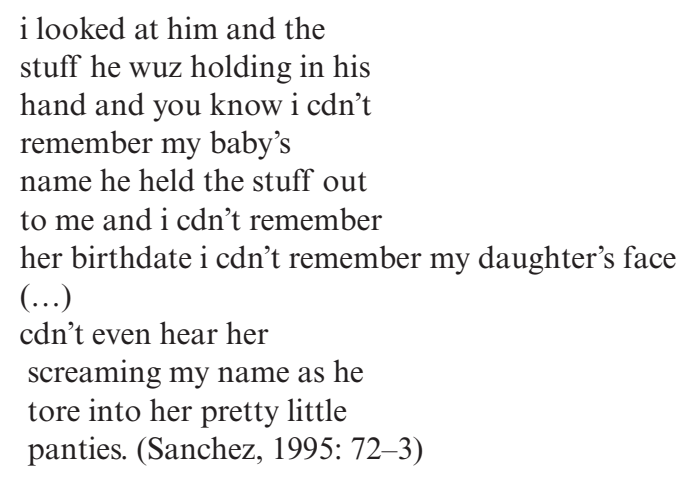

The psychic dislocation in the poem speaks to and for the distance drug addiction has drawn between her and better judgment. The absence she 
describes as a memory that she could not realize becomes ephemeral. Laub describes this type of mystic disassociation as an effect of "the speakers about trauma on some level prefer[ing] silence so as to protect themselves from the fear of being listened to -and of listening to themselves" (Laub, 1992: 58). The contact with a traumatic event as she receives the drugs and loses her daughter speaks to the aforementioned space in between listening and witnessing - a space that breaks the silence of bearing witness and articulates the audible and traumatic event as testimony. After leaving the crack house, she describes, "when we got home she / wdn't talk to me ... just sat and / looked at me with her eyes til / i had to get outa there" (Sanchez, 1995: 73-74). Her daughter's eyes are a mark of trauma. The wound has rendered her daughter voiceless, a silence that marks the loss of her innocence. Thus the text revisits the psychic wounds outlined in her mother's story of drug abuse and the daughter's premature, violent, and pedophilic experience with sex. This moment traces the inability of her mother to act as witness and speak of her own losses as a victim of the social and political system historically at odds with her race and gender -a underlying problem which causes this debasement of her character.

As Caruth explains in Unclaimed Experiences, trauma narrative "constitutes the new mode of reading and of listening that both the language of trauma, and the silence of its mute repetition of suffering, profoundly and imperatively demand" (Caruth, 1996: 9). Along the same lines Laub discusses the position of witness and its multifaceted outcome in reading traumatic restatements: "the level of being a witness to oneself within the experience; the level of being a witness to the testimonies of others; and the level of being a witness to the process of witnessing itself" (Laub, 1992: 75). Culminating in tonal range and libidinous overtones, Sanchez's "Poem for Some Women" parallels the level of witness at the end of the poem as it reads, "shortening bread ran away last week / peekaboo i see you and / you and you and you / and you" (Sanchez, 1995: 74). In each "you" there is what Caruth refers to as "mute repetitions of suffering", or in the words of Hal Foster a "rupture" in the real (Foster, 1996: 132). From his Lacanian analysis of the "real" as literally the traumatic event, the repetition, in this analysis, relates to the repetition of the "you" in Sanchez's poem. The you that touches, abstracts, and questions the reality of, or trauma each "you" that access a different trauma-likely, a different narrative. The title alone, "Poem for Some Women", is indicative of the range of suffering from drug abuse and sexual abuse that affects some women from both sides of the coin. In other words, the "peekaboo i see you ... and you" can refer to the women who can't break free from an addiction that ruins them and their children, like the mother in Sanchez's poem and like the child, who is lost in the effects her mother's addiction has had on her body. And furthermore, in witnessing each other's trauma both Black females are caught in a cycle of woundedness. Sanchez reflects in both poems the impossibility of evolution (the crisis of death) without cognizance of obstacles internalized by racism, sexism, and patriarchy (the crisis of life). These poems are the between story -they illuminate the unbreakable relationship between both. In each "you" there is a form of witness and the choice of its repetition is a form of testimony that encapsulates multiple stories of psychic trauma in this poem.

\section{CONCLUSION}

Music, literature, and art, are some of the genres used by African Americans to (re)claim and authenticate their voice in American history -a voice that materializes an autonomous identity and analysis of their tumultuous past. Reclaiming histories long forgotten and stories that have been silenced or untold were important factors in the Black struggle. Contextualizing these struggles created a political space not previously afforded to marginalized subjects. Poetry framed Black voice, identity, and consciousness for many Black feminists. Locating the violence Black men have inflicted in the African American community makes possible a discourse on race, gender, and insidious abuse within a paradigm of white supremacist social and economic hierarchies. However, this argument does not excuse Black men's violence against Black women. Rather, Sanchez and Clifton's poetry implores Black men and readers not to continue the cycle. It is vital that they become aware of the participants and the factors leading to their cyclical wounding. Psychic wounding is an important part of the struggle. The quandary lies in the image of Black men who, in an attempt to authenticate their manhood, oppress Black women in ways similar to the white men oppressors that committed the violent rape and silencing of Black women during slavery.

In an interview with Bill Moyers, Clifton asserts, "we cannot ignore history. History doesn't go away. The past isn't back there, the past is here too" (Moyers et al., 1995, 87). How can the oppressed become liberated with an abstract understanding of the past that will continue the cycle of oppression? The oppressed are attuned to the way of life that keeps them in need of the oppressor. This is the silence that can ruin the chance for liberation. Rape and race relates to the discourse of trauma in Sanchez and Clifton's texts and its discourse on trauma as it relates to psychic pains elucidated through slavery. Interpolated in these narratives are the silenced voices, and a distinct look at how Black women define the psychosexual effects of slavery, 
past and present. In her poem, "Forced Entry", contemporary Black poet Mariahadessa Ekere Tallie (2011) speaks about a cycle continued into today's literature. The psychosexual effects rape has on the Black woman's psyche are strongly felt in this poem:

\author{
I wish this wasn't my story \\ but it is \\ a million times over \\ and just when I think it has gone away \\ it reappears at my doorstep \\ in another woman's face \\ so this is our story \\ and it will be ours \\ until we don't have to claim it anymore \\ and wounded eyes will tell it \\ even when we don't'"(Tallie, 2011: 29-34, 38-40, 49-50).
}

Poetry has the ability to speak about race, gender, and trauma with the same fluency it did during the various liberation movements in the 20th century. Violence to the Black body is still an important factor in the continuous dialogue on healing. Like Sanchez and Clifton express in their pedagogical creed, education and the nurturing and development of Black consciousness is an integral part of healing.

Sanchez and Clifton, and more recently Tallie, get it right by tapping into the experience as closely as is possible in a world of literature that rejects an honest discussion of Black traumatic experiences. Overall this thesis, through attention to trauma theory and Black women's poetry, puts forth a reading of this poetry that exposes the incessant wounding echoed in African American literature. Wrestling with the critical discourse on African American women's literature advances the concepts of traumatic events as they are conceptualized in various forms of expression. In Foster's book The Return of the Real, he posses a profound question: "Why this fascination with trauma, this envy of abjection, today?" (Foster, 1996: 166). In this case, it is the resounding silence that violently tells the stories of Black subjects -when words may never competently express the wound.

\section{ACKNOWLEDGEMENTS}

This paper was completed in partial fulfillment of the Master of Arts program at Hunter College. Many thanks to my mentors Professor Patricia Milanes, for sparking my interest in trauma theory, and Dr. Mychel Namphy for my devotion to African American literature. To my family, thank you for helping me perceive the witnessing and heal the silences.

\section{REFERENCES}

Baker, Jamie D. (2012) "Learning to Listen: An Examination of Trauma in 20th Century Multicultural American Poetry". Diss. Indiana University of Pennsylvania, Indiana County.

Barnett, Pamela (1997) The Language of Rape: Sexual Violence in Novels by Faulkner, Naylor, and Morrison. Diss. Emory University, Ann Arbor, Michigan.

Breines, Wini (2006) The Trouble between Us: An Uneasy History of White and Black Women in the Feminist Movement. Oxford UP, Oxford. http://dx.doi.org/10.1093/acprof:oso/ 9780195179040.001.0001

Brown, Laura S. (2004) "Feminist Paradigms of Trauma Treatment". Psychotherapy: Theory, Research, Practice, Training, 41.4: 464-71. http://dx.doi.org/10.1037/0033-3204.41.4.464

Caruth, Cathy (1996) Unclaimed Experience: Trauma, Narrative, and History. Johns Hopkins UP, Baltimore.

Christian, Barbara; Bowles, Gloria; Fabi, M. Giulia and Keizer, Arlene R (2007) New Black Feminist Criticism, 1985-2000. University of Illinois, Urbana.

Clifton, Lucille (1987) Good Woman: Poems and a Memoir, 1969-1980. BOA Editions, Brockport, NY.

Clifton, Lucille. (1993) The Book of Light. Copper Canyon, Port Townsend, WA

Clifton, Lucille (2000) Blessing the Boats: New and Selected Poems, 1988-2000. BOA Editions, Rochester, NY.

Courtois, Christine (1997) "Healing the Incest Wound: A Treatment Update with Attention to Recovered-memory Issues". American Journal of Psychotherapy, 51.4: 464-96.

Cucinella, Catherine (2002) Contemporary American Women Poets: An A-to-Z Guide. Greenwood, Westport.

Davis, Angela Y. (1985) Violence against Women and the Ongoing Challenge to Racism. Kitchen Table, Latham, NY.

Davis, Elsa (2002) "Lucille Clifton and Sonia Sanchez: A Conversation". Callaloo, 25.4: 1038-1074. http://dx.doi. org/10.1353/cal.2002.0149

Felman, Shoshana and Laub, Dori (1991) Testimony: Crises of Witnessing in Literature, Psychoanalysis, and History. Routledge, New York.

Foster, Hal (1996) The Return of the Real: The Avant-garde at the End of the Century. MIT, Cambridge, MA.

Frost, Elisabeth A. and Hogue, Cynthia (2006) "Jayne Cortez". In Innovative Women Poets: an Anthology of Contemporary Poetry and Interviews, edited by Frost, Elisabeth and Hogue, Cynthia, University of Iowa, Iowa City, pp. 69-91.

Grogan, Christine L. (2011) "The Wound and the Voiceless": The Insidious Trauma of Father-Daughter Incest in Six American Texts. Graduate School Theses and DIssertations. University of South Florida. Tampa. http://scholarcommons.usf.edu/etd/3129/ [accessed 02/November/2013]

Haaken, Janice (2002) "Toward a New Feminist Theory of Rape': The Seductions of Theory". Signs: Journal of Women in Culture and Society, 27.3: 781-787. http://dx.doi. org/10.1086/337936

Herman, Judith Lewis (1992) Trauma and Recovery. Basic, NY.

Hesford, Wendy (2004) "Rhetorical Projections and Silences". JAC, 24.3: 785-797. http://www.jaconlinejournal.com/archives/ vol24.3/hesford-rhetorical.pdf [accessed 22/July/2012]

Hooks, Bell (1993) Sisters of the Yam: Black Women and Selfrecovery. South End, Boston, MA.

Jacobs, Harriet (1987) "Incidents In The Life Of A Slave Girl". In The Classic Slave Narratives, edited by Gates, Henry Louis, Penguin, New York, pp. 437-668.

Johnson, Guy (1990) "Double Meaning in Popular Negro Blues". In Mother Wit from the Laughing Barrel Readings in the Interpretation of Afro-American Folklore, edited by Alan Dundes, University of Mississippi, Jackson, MS, pp. $258-268$.

Jordan, June (2005) Directed by Desire: The Collected Poems of June Jordan. Copper Canyon, Port Townsend, WA.

Lacan, Jacques (1988) Seminar II: The Ego in Freud's Theory and in the Technique of Psychoanalysis. Trans. Sylvana 
Tomaselli. Ed. Jacques-Alain Miller. Cambridge University Press, Cambridge.

Laub, Dori, MD. (1992) "Bearing Witness, or the Vicissitudes of Listening". In Testimony: Crises of Witnessing in Literature, Psychoanalysis, and History, edited by Felman, Shoshana and Laub, Dori, Routledge, New York, pp. 7-74.

Laub, Dori and Podell, Daniel (1995) "Art and Trauma". International Journal of Psycho-Analysis, 76: 995-1005.

Lorde, Audre (1984) Sister Outsider: Essays and Speeches. Crossing, NY.

Marcus, Sharon (2002) "Fighting Bodies, Fighting Words: A Theory and Politics of Rape Prevention". In Gender Struggles: Practical Approaches to Contemporary Feminism, edited by Mui, Constance L., Murphy Julien S., Rowman \& Littlefield, Lanham, pp. 166-185.

Mardorossian, Carine M. (2002) "Toward a New Feminist Theory of Rape". Signs: Journal of Women in Culture and Society, 27.3: 743-775. http://dx.doi.org/10.1086/337938

Moyers, Bill D.; Haba, James and Grubin, David (1995) The Language of Life: A Festival of Poets. Doubleday, New York.

Pollard, Cherise (1994) "Sexual Subversions, Political Inversions: Women's Poetry and the Politics of the Black Arts Movement". In New Thoughts On The Black Arts Movement, edited by Crawford, Margo N. and Collins, Lisa G., Oxford UP, New York, pp. 173-186.

Radstone, Susannah (2007) "Trauma Theory: Contexts, Politics, Ethics". Paragraph, 30.1: 9-29. http://dx.doi.org/10.3366/ prg. 2007.0015

Raymond, Yasmil (2007) "Maladies of Power: A Kara Walker Lexicon". In Kara Walker: My Complement, My Enemy, My Oppressor, My Love, edited by Vergne, Phillipe, Walker Art Center Minneapolis, pp. 347-370. http://media.walkerart.org/pdf/KWlexicon.pdf [accessed 22/July/2012].

Roberts, Jessica F. (2005) "A Prayer for Mourning: Seduction and Trauma in Carolivia Herron's 'Thereafter
Johnnie"”. Callaloo, 28.4: 1060-073.http://dx.doi.org/10.1353/ cal.2006.0035

Root, Maria P. (1992) "Reconstructing the Impact of Trauma on Personality". In Personality and Psychopathology: Feminist Reappraisals, edited by Brown, Laura S. and Ballou, Mary B., Guilford, New York, pp. 229-266.

Rothberg, Michael (2000) Traumatic Realism: The Demands of Holocaust Representation. University of Minnesota, Minneapolis.

Sanchez, Sonia (1984) Homegirls and Handgrenades: A Collection of Poetry and Prose. Thunder's Mouth, New York.

Sanchez, Sonia (1985) I've Been a Woman: New and Selected Poems. Third World, Chicago

Sanchez, Sonia (1995) Wounded in the House of a Friend. Beacon, Boston, MA.

Shange, Ntozake (1977) For Colored Girls Who Have Considered Suicide, When the Rainbow Is Enuf: A Choreopoem. MacMillan, New York.

Spillers, Hortense J. (1987) "Mama's Baby, Papa's Maybe: An American Grammar Book". Diacritics, 17.2: 64-81. http:// dx.doi.org/10.2307/464747

Tallie, Mariahadessa Ekere (2011) Karma's Footsteps. Flipped Eye, London.

Walker, Kara (1998) "Burn". Photograph. The Speyer Family Collection, New York. http://www-tc.pbs.org/art21/files/ images/walker-draw2-001.jpg [accessed 22/July/2012].

Wallace, Michele (1979) Black Macho and the Myth of the Superwoman. Dial, New York.

West, Cornel (1993) Race Matters. Beacon, Boston.

Wunker, Erin (2007) "Timing 'I': An Investigation of the Autofictional 'I' in Gail Scott's Heroine". ESC 33.1-2: $147-64$.

Zepf, Siegfried and Zepf, Florian D. (2008) "Trauma and Traumatic Neurosis: Freud's Concepts Revisited". The International Journal of Psychoanalysis, 89.2: 331-53. http:// dx.doi.org/10.1111/j.1745-8315.2008.00038.x 